\title{
Front Matter: Volume 7960
}

, "Front Matter: Volume 7960," Proc. SPIE 7960, Coherent Optical Communication: Components, Subsystems, and Systems, 796001 (24 January 2011); doi: 10.1117/12.888706

SPIE. Event: SPIE OPTO, 2011, San Francisco, California, United States 


\section{PROCEEDINGS OF SPIE}

\section{Coherent Optical Communication: Components, Subsystems, and Systems}

\section{Guifang Li}

Dieter Stefan Jäger

Editors

25-27 January 2011

San Francisco, California, United States

Sponsored and Published by

SPIE 
The papers included in this volume were part of the technical conference cited on the cover and title page. Papers were selected and subject to review by the editors and conference program committee. Some conference presentations may not be available for publication. The papers published in these proceedings reflect the work and thoughts of the authors and are published herein as submitted. The publisher is not responsible for the validity of the information or for any outcomes resulting from reliance thereon.

Please use the following format to cite material from this book:

Author(s), "Title of Paper," in Coherent Optical Communication: Components, Subsystems, and Systems, edited by Guifang Li, Dieter Stefan Jäger, Proceedings of SPIE Vol. 7960 (SPIE, Bellingham, WA, 2011) Article CID Number.

ISSN 0277-786X

ISBN 9780819484970

Published by

SPIE

P.O. Box 10, Bellingham, Washington 98227-0010 USA

Telephone +1 3606763290 (Pacific Time) · Fax +1 3606471445

SPIE.org

Copyright (C) 2011, Society of Photo-Optical Instrumentation Engineers

Copying of material in this book for internal or personal use, or for the internal or personal use of specific clients, beyond the fair use provisions granted by the U.S. Copyright Law is authorized by SPIE subject to payment of copying fees. The Transactional Reporting Service base fee for this volume is $\$ 18.00$ per article (or portion thereof), which should be paid directly to the Copyright Clearance Center (CCC), 222 Rosewood Drive, Danvers, MA 01923. Payment may also be made electronically through CCC Online at copyright.com. Other copying for republication, resale, advertising or promotion, or any form of systematic or multiple reproduction of any material in this book is prohibited except with permission in writing from the publisher. The CCC fee code is 0277-786X/11/ \$18.00.

Printed in the United States of America.

Publication of record for individual papers is online in the SPIE Digital Library.

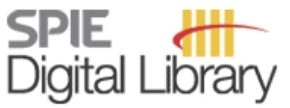

SPIEDigitalLibrary.org

Paper Numbering: Proceedings of SPIE follow an e-First publication model, with papers published first online and then in print and on CD-ROM. Papers are published as they are submitted and meet publication criteria. A unique, consistent, permanent citation identifier (CID) number is assigned to each article at the time of the first publication. Utilization of CIDs allows articles to be fully citable as soon they are published online, and connects the same identifier to all online, print, and electronic versions of the publication. SPIE uses a six-digit CID article numbering system in which:

- The first four digits correspond to the SPIE volume number.

- The last two digits indicate publication order within the volume using a Base 36 numbering system employing both numerals and letters. These two-number sets start with 00, 01, 02, 03, 04, $05,06,07,08,09,0 A, 0 B \ldots 0 Z$, followed by 10-1Z, 20-2Z, etc.

The CID number appears on each page of the manuscript. The complete citation is used on the first page, and an abbreviated version on subsequent pages. Numbers in the index correspond to the last two digits of the six-digit CID number. 


\section{Contents}

vii Conference Committee

ix Photonic devices for next-generation broadband fiber access networks (Plenary Paper) [7958-01]

L. G. Kazovsky, S.-H. Yen, S.-W. Wong, Stanford Univ. (United States)

$\mathrm{xv} \quad$ Higher-order modulation formats for spectral-efficient high-speed metro systems (Plenary Paper) [7959-01]

R. Freund, M. Nölle, M. Seimetz, J. Hilt, J. Fischer, R. Ludwig, C. Schubert, H.-G. Bach,

K.-O. Velthaus, M. Schell, Fraunhofer-Institute for Telecommunications,

Heinrich-Hertz-Institut (Germany)

\section{OPTICAL COMMUNICATIONS PLENARY SESSION}

796002 Advances in coherent detection algorithms (Plenary Paper) [7960-01]

J. C. Rasmussen, T. Hoshida, T. Tanimura, H. Nakashima, S. Oda, Fujitsu Labs. Ltd. (Japan);

Z. Tao, L. Li, Fujitsu R\&D Ctr. (China)

OFDM FOR ACCESS, METRO AND COHERENT COMMUNICATIONS: JOINT SESSION WITH CONFERENCE 7959

796004 Real-time coherent OFDM transmission (Invited Paper) [7960-03]

N. Kaneda, T. Pfau, Alcatel-Lucent (United States); Q. Yang, Wuhan Research Institute of Posts \& Telecommunications (China); Y. K. Chen, Alcatel-Lucent (United States)

796005 Low cost direct modulation and coherent detection optical OFDM for metro applications [7960-04]

N. Sheffi, D. Sadot, Ben-Gurion Univ. of the Negev (Israel)

796006 Single-carrier versus sub-carrier bandwidth considerations for coherent optical systems (Invited Paper) [7960-05]

J. D. McNicol, Infinera Canada (Canada); V. Dangui, Infinera (United States); H. Sun,

D. Krause, K.-T. WU, Infinera Canada (Canada); M. Mitchell, D. Welch, Infinera (United States)

COMPONENT TECHNOLOGIES FOR ACCESS, METRO AND COHERENT COMMUNICATIONS: JOINT SESSION WITH CONFERENCES 7958 AND 7959

796008 Coherent optical component technologies for WDM transmission systems (Invited Paper) [7960-07]

S. Mino, K. Murata, T. Saida, I. Ogawa, NTT Corp. (Japan) 
7960 0A Developing accurate simulations for high-speed fiber links [7960-09]

S. Searcy, A. Stark, Y.-T. Hsueh, T. Detwiler, Georgia Institute of Technology (United States);

S. Tibuleac, ADVA Optical Networking (United States); G. Chang, S. E. Ralph, Georgia

Institute of Technology (United States)

\section{CODING AND ALGORITHMS}

7960 OB Rate-adaptive modulation and coding for optical fiber transmission systems (Invited Paper) [7960-10]

G.-H. Gho, J. M. Kahn, Stanford Univ. (United States)

7960 OD Asynchronously sampled blind source separation for coherent optical links [7960-12] T. F. Detwiler, S. M. Searcy, A. J. Stark, S. E. Ralph, Georgia Institute of Technology (United States); B. E. Basch, Verizon (United States)

\section{COMPENSATION OF IMPAIRMENTS}

7960 OF Interchannel nonlinear impairment compensation by advanced split-step method (Invited Paper) [7960-14]

F. Yaman, E. Mateo, T. Wang, NEC Labs. America, Inc. (United States); G. Li, CREOL, The College of Optics \& Photonics, Univ. of Central Florida (United States)

$7960 \mathrm{OH} \quad$ Analysis and mitigation of Mach-Zehnder modulator nonlinearity in coherent optical OFDM system in the presence of high peak power [7960-17]

Y. London, D. Sadot, Ben-Gurion Univ. of the Negev (Israel)

7960 ol Avoiding fiber nonlinearities by choice of modulation format [7960-18]

T. F. Detwiler, S. M. Searcy, A. J. Stark, Georgia Institute of Technology (United States);

B. E. Basch, Verizon (United States); S. E. Ralph, Georgia Institute of Technology (United States)

\section{HIGH-ORDER MODULATION FORMATS}

7960 OK High-order QAM transmission for the future optical transport network beyond $100 \mathrm{~Gb} / \mathrm{s}$ (Invited Paper) [7960-20]

T. Kobayashi, NTT Corp. (Japan)

$7960 \mathrm{OL}$ Advances in coherent optical modems and 16-QAM transmission with feedforward carrier recovery (Invited Paper) [7960-21]

R. Noé, S. Hoffmann, Univ. of Paderborn (Germany); C. Wördehoff, Bielefeld Univ.

(Germany); A. Al-Bermani, M. El-Darawy, Univ. of Paderborn (Germany)

7960 0M Spectrally efficient polymer optical fiber transmission (Invited Paper) [7960-23]

S. Randel, Alcatel-Lucent (United States); C.-A. Bunge, Hochschule für Telekommunikation Leipzig (Germany) 
7960 OQ Photonic generation of RF multiple carriers using a mode-locked laser and a single photodiode [7960-27]

P. Ghelfi, Consorzio Nazionale Interuniversitario per le Telecomunicazioni (Italy): G. E. Serafino, F. Fresi, CEIICP, Scuola Superiore Sant'Anna (Italy); G. Villanueva, P. Pérez-Millán, J. L. Cruz, Univ. de València (Spain); F. Berizzi, Univ. di Pisa (Italy); A. Bogonia, Consorzio Nazionale Interuniversitario per le Telecomunicazioni (Italy)

7960 OR Fiber-coupled superconducting nanowire single photon detector for quantum key distribution [7960-28]

L. Zhang, Q. Zhao, L. Kang, J. Chen, C. Cao, P. Wu, Univ. of Nanjing (China)

7960 OS Coherent state statistics from time-resolved photon counting [7960-29]

H. Ravi, A. Prabhakar, Indian Institute of Technology Madras (India)

Author Index 
Downloaded From: https://www.spiedigitallibrary.org/conference-proceedings-of-spie on 25 Apr 2023

Terms of Use: https://www.spiedigitallibrary.org/terms-of-use 


\title{
Conference Committee
}

\author{
Symposium Chair
}

Liang-Chy Chien, Kent State University (United States)

Symposium Cochairs

E. Fred Schubert, Rensselaer Polytechnic Institute (United States)

Klaus P. Streubel, OSRAM GmbH (Germany)

Program Track Chair

Benjamin Dingel, Nasfine Photonics, Inc. (United States)

\section{Conference Chairs}

Guifang Li, CREOL, The College of Optics and Photonics, University of Central Florida (United States)

Dieter S. Jäger, Universität Duisburg-Essen (Germany)

Program Committee

Young-Kai Chen, Alcatel-Lucent Bell Laboratories (United States)

Benjamin Dingel, Nasfine Photonics, Inc. (United States)

Jin Hong, Opnext, Inc. (United States)

Sander L. Jansen, Nokia Siemens Networks (Germany)

Alan C. Nilsson, Infinera Corporation (United States)

loannis Roudas, University of Patras (Greece)

Akihide Sano, NTT Network Innovation Laboratories (Japan)

Atul K. Srivastava, OneTerabit (United States)

Session Chairs

Optical Communications Plenary Session

Benjamin Dingel, Nasfine Photonics, Inc. (United States)

Werner Weiershausen, Deutsche Telekom AG (Germany)

1 OFDM for Access, Metro and Coherent Communications: Joint Session with Conference 7959

Atul K. Srivastava, OneTerabit (United States)

Guifang Li, CREOL, The College of Optics and Photonics, University of Central Florida (United States) 
2 Component Technologies for Access, Metro and Coherent

Communications: Joint Session with Conferences 7958 and 7959

Guifang Li, CREOL, The College of Optics and Photonics, University of Central Florida (United States)

Werner Weiershausen, Deutsche Telekom AG (Germany)

3 Coding and Algorithms

Guifang Li, CREOL, The College of Optics and Photonics, University of Central Florida (United States)

4 Compensation of Impairments

Guifang Li, CREOL, The College of Optics and Photonics, University of Central Florida (United States)

$5 \quad$ High-Order Modulation Formats

Guifang Li, CREOL, The College of Optics and Photonics, University of Central Florida (United States)

6 Optical Networks: Joint Session with Conferences 7958 and 7959

Werner Weiershausen, Deutsche Telekom AG (Germany) 